\title{
Game Anti Narkoba Berbasis Multi-Platform
}

\author{
Aziz Mufa'adhi ${ }^{*}$, Endah Sudarmilah ${ }^{1}$ \\ ${ }^{1}$ Program Studi informatika, Fakultas Komunikasi dan Informatika \\ Universitas Muhammadiyah Surakarta \\ *Azmuf94@gmail.com, Endah.Sudarmilah@ums.ac.id
}

\begin{abstract}
ABSTRAK
Narkoba memiliki dampak buruk bagi generasi muda. Pencegahan dan pemberantasan penyalahgunaan narkoba harus dilakukan untuk melindungi masa depan bangsa. Pengenalan dampak negative dari penyalahgunaan narkoba melalui game sebagai sarana sosialisasi untuk menekan jumlah penyalahgunaan narkoba. Dalam pembuatannya game ini membahas tentang dampak buruk dari Narkoba. Game ini dibuat dengan metode SDLC (System Development Life Cycle) yang diturunkan menjadi tahapan sistem secara berurutan diawali dengan membuat storyboard permainan, kemudian diimplementasikan dengan software pendukung untuk membuat aplikasi game. Berdasarkan hasil pengujian black box dan pengujian calon pengguna dilakukan dengan cara meminta responden untuk mencoba game yang dibuat kemudian mengisi kuesioner yang disediakan. sebanyak $96,6 \%$ responden menyatakan game ini berjalan baik. Game ini bertujuan untuk mengenalkan dampak buruk narkoba dan menghindarkan orang untuk menyalahgunakan atau memakai narkoba. Game dapat dioperasikan di sistem operasi android dan komputer desktop berbasis Windows sehingga game ini bersifat multi-platform.
\end{abstract}

Kata kunci : Game, Narkoba, Android, computer, multi-platform

\section{Pendahuluan}

Narkoba dan obat terlarang menyebabkan dampak negatif bagi pemakainya. Dampak negative ini sudah pasti merugikan dan sangat buruk efeknya bagi kesehatan. Dampak negatif sudah pasti merugikan dan sangat buruk efeknya bagi kesehatan mental dan fisik. Ancaman penyalahguanaan narkoba bersifat multi dimensional: kesehatan, ekonomi, social, dan pendidikan [1]. Tidak sedikit pula dari generasi muda jaman sekarang telah menyalahgunakan narkoba dan zat terlarang sebagai gaya hidup hidup dijaman modern. Upaya pencegahan penyalahguanaan narkoba sudah menjadi tangguang jawab bersama. Dalam hal ini pihak orang tua, guru, masyarakat harus turut berperan aktif dalam mewaspadai ancaman narkoba.

Untuk menangani permasalahan diatas diperlukan sebuah pendekatan. Metode ini dapat diwujudkan dengan media game. Dengan adanya game sebagai media pendekatan diharapkan anak dapat mengenal berbagai ancaman dan dampak buruk narkoba serta menghindarinya. Game merupakan alat untuk mengajar karena mengandung prinsip pembelajaran, dengan adanya level-level yang sulit [3].

Menurut Dewi Edugame adalah sebuah permainan yang dibuat untuk merangsang daya pikir untuk menghindari masalah [2]. Jenis game yang dipilih bukan hanya karena tujuan pengguanaan fungsi game itu sendiri tapi juga untuk media pembelajaran.
Williams dalam jurnal berjudul "the effect of dissociation, game controllers, and $3 \mathrm{D}$ versus $2 \mathrm{D}$ on presence and enjoyment" mengatakan dalam hal variabel bentuk media, jenis game controller akan bervariasi serta persepsi pergerakan obyek dalam permainan [7]. Persepsi gerakan akan disesuaikan dengan memiliki pemain melihat permainan baik 2D atau 3D.

Construct 2 adalah sebuah program untuk membuat permainan computer dengan HTML 5, tanpa harus untuk memiliki dasar pemrograman. Construct 2 digunakan untuk membuat permainan 2D, dan hadir dengan banyak tools yang membuatnya mudah. Kemudahan dan kelebihan construct 2 dalam membuat game yang hanya menarik dan mengambil object yang tersedia, menambah perintah, dan mambuat segala sesuatu menjadi hidup dengan peristiwa. Game dari construct 2 dapat dijalankan pada platform berbasis web store, pc desktop, dan mobile seperti android, dan IOS. Construct 2 tampilan mudah dimengerti fitur-fiturnya termasuk peristiwa sistem Powerfull berfokus pada logika [6].

Dari permasalahan tentang narkoba diharapkan dalam pembuatan game anti narkoba sebagai solusi pendekatan dan media pembelajaran tentang dampak buruk dan bahaya narkoba.

\section{Metode Penelitian}

Metode penelitian yang diguanakan peneliti ini berupa metode penelitian System Development Life circle (SDLC). Hal ini dilakukan agar menghasilkan penelitian 
yang baik dan sesuai dengan tujuan penelitian. SDLC dapat digambarkan dalam diagram alir gambar 1 .

Gambar 2 merupakan storyboard halaman utama, Gambar 3 sampai dengan 5 adalah gambaran storyboard game level 1 sampai dengan 3 .

Ketika user membuka pertama kali aplikasi game ini terdapat empat menu utama. Game ini menggunakan karakter polisi atau tentara yang membawa senjata api sebagi senjata yang berfungsi untuk mengalahkan musuhmusuh narkoba. Dan karakter musuh ganja berupa jin dan berkepala daun ganja, morfine berupa jarum suntik dan ophium monster raksasa dari tanaman ophium. Narkoba dapat digolongkan sebagai berikut (a) opioda, misalnya morfine,heroin,petidin dan candu (b) ganja atau kaabis, mariyuana dan hashish [1].

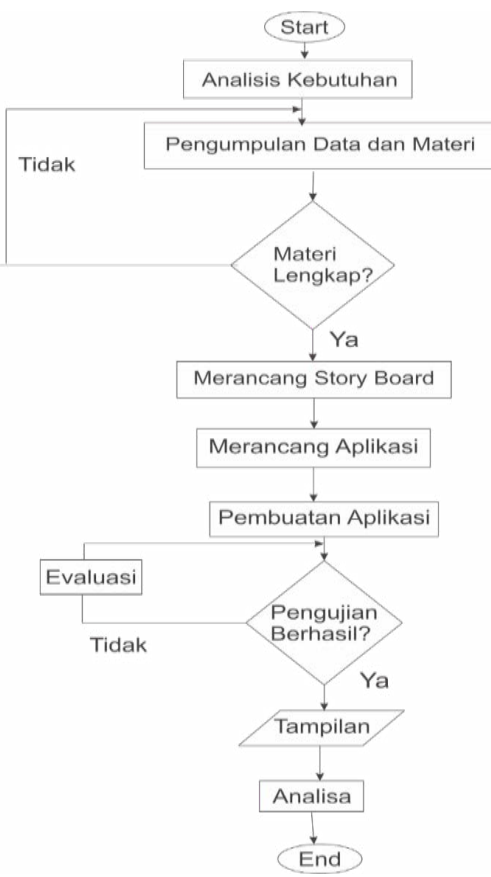

Gambar 1 Diagram Alir Penelitian

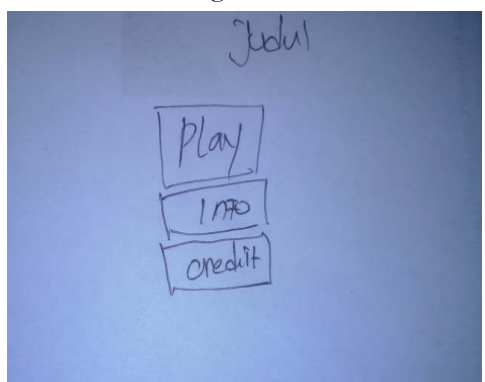

Gambar 2. Halaman Utama

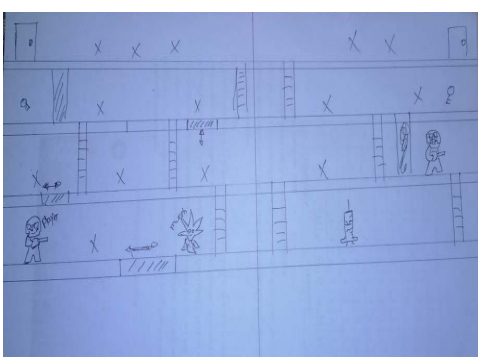

Gambar 3. Storyboard game level 1

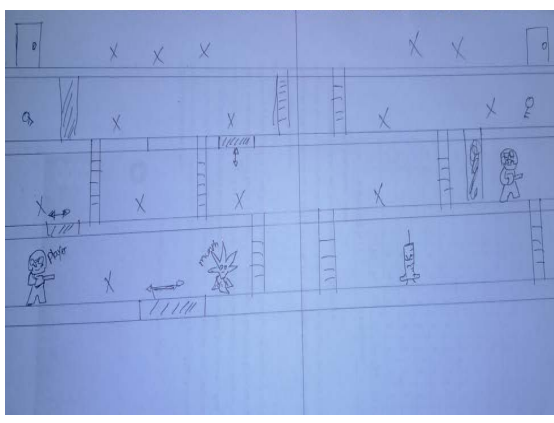

Gambar 4. Storyboard game level 2

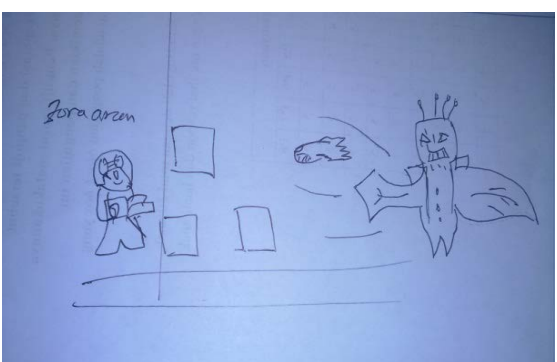

Gambar 5. Storyboard game level 3

\subsection{Pembuatan Aplikasi}

Pembuatan aplikasi game edukasi ini menggunakan hardware dan software yaitu :

\subsubsection{Software}

Coreldraw X5 untuk membuat desain objek 2D,

a) Format factory untuk menconvert audio .mp4 menjadi .ogg

b) Construct 2 untuk pembuatan game secara keseluruhan.

c) Cocoon.io untuk mengeksport ke android dan NW.js untuk mengeksport .exe

\subsubsection{Hardware}

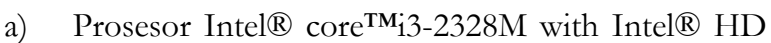
graphics $3000 \mathrm{M}$

b) Hardisk $500 \mathrm{~GB}$

c) RAM 4 GB DDR3 Memory

\subsection{Pengujian}

Pengujian game ini dilakukan setelah selesai pembuatan game edukasi dengan black box dan pengujian pengguna dengan pengisian kuesioner dari responden

\section{Hasil dan Pembahasan}

Aplikasi edukasi Game untuk pengenalan nama benda ini dibuat menggunakan software Construct 2 r.221 dimana Construct 2 merupakan software yang terintegrasi untuk membuat game 2 Dimensi berbasis HTML5, serta Construct 2 mendukung berbagai platform seperti PC, iPhone, Ipad, Android, dan browser. Aplikasi ini tidak menggunakan bahasa pemrograman khusus, karena semua perintah yang digunakan pada game diatur dalam EvenSheet yang terdiri dari Event dan Action. 


\subsection{Hasil Aplikasi}

\subsubsection{Tampilan aplikasi}

Halaman aplikasi ini merupakan halaman utama ketika user membuka aplikasi. Gambar 6 merupakan tampilan dari halaman menu.

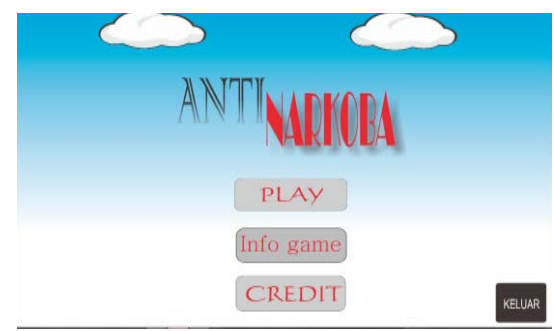

Gambar 6. Halaman menu

Halaman menu terdiri dari menu yang akan membawa user pada halaman materi dari masing-masing item. Kemudian ada tombol "Permainan" yang mana membawa user pada halaman game, sehingga user dapat bermain game yang berhubungan dengan materi. Dan info game sebagai halaman yang membantu user dalam menjalankan aplikasi game tersebut.

\subsubsection{Tampilan level}

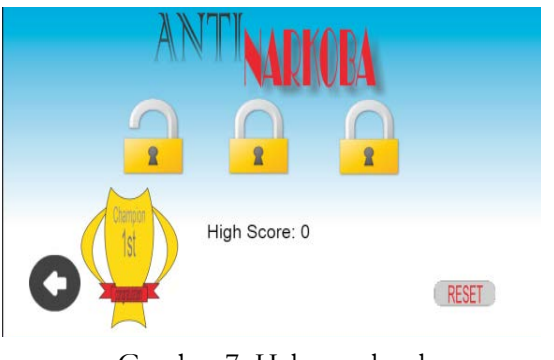

Gambar 7. Halaman level

\subsubsection{Halaman Permainan}

Halaman Permainan terdiri dari 3 Level yang memiliki kategori berbeda yang mana tiap level akan terkunci dan dapat di buka apabila menyelesaikan level awal satu persatu untuk mendapatkan skor dan bintang.. Tampilan halaman Permainan pada gambar 8 sampai dengan 10 .

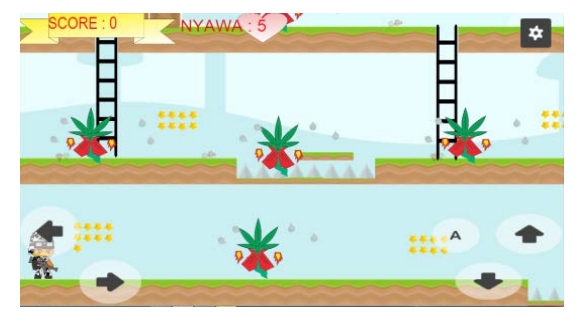

Gambar 8. Permainan level 1 "Ganja"

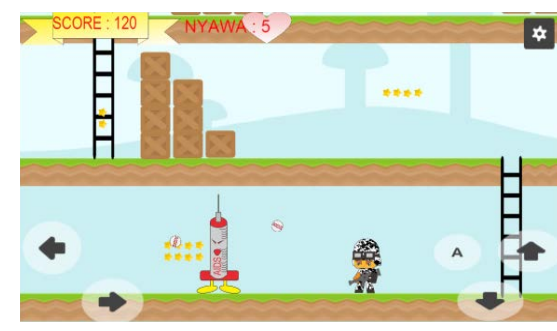

Gambar 9. Permainan level 2 "Morfine"

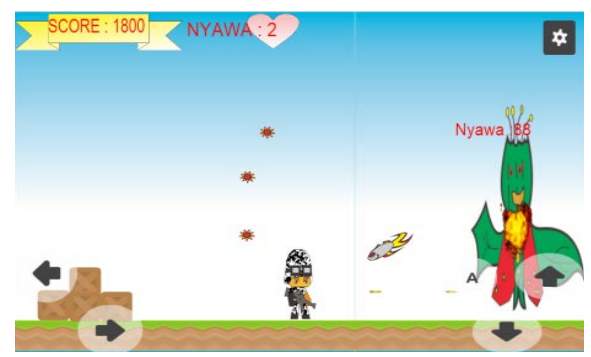

Gambar 10. Permainan level 3 "Ophium"

\subsubsection{Halaman Petunjuk}

Halaman petunjuk berisi tentang panduan untuk user dalam penggunaan aplikasi game ini. Halaman petunjuk ada pada gambar 11 di bawah ini.

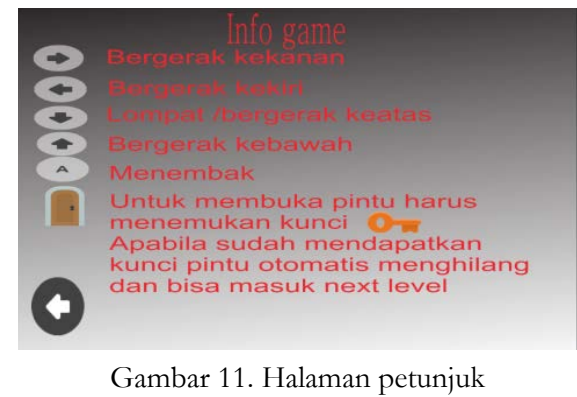

\subsection{Pengujian}

\section{a. Uji Validitas}

Menurut Priyatno [5] Uji validitas adalah ketepatan suatu instrumen dalam mengukur apa yang ingin diukur. Uji validitas sering digunakan untuk mengukur ketepatan item dalam kuisioner. Validitas item ditujukkan dengan adanya korelasi.

Menurut Priyatno [5] jika $\mathrm{r}$ hitung $\geq \mathrm{r}$ tabel ( uji 2 sisi dengan sig. 0,05) maka item pertanyaan/ instrumen dinyatakan valid.

Hasil uji validitas pada siswa MI Gotong Royong dengan acuan tabel r : 0,308 didapat dari N suatu jumlah sampel : 41 dalam tabel 1.

Tabel 1. Hasil uji validitas

\begin{tabular}{clll}
\hline Korelasi & r Hitung & r Tabel & $\begin{array}{l}\text { Hasil Uji } \\
\text { Validitas }\end{array}$ \\
\hline P1 dengan Ptotal & 0.479 & 0,349 & Valid \\
P2 dengan Ptotal & 0.432 & 0,349 & Valid \\
P3 dengan Ptotal & 0.705 & 0,349 & Valid \\
P4 dengan Ptotal & 0.705 & 0,349 & Valid \\
P5 dengan Ptotal & 0,680 & 0,349 & Valid \\
P6 dengan Ptotal & 0.705 & 0,349 & Valid \\
P7 dengan Ptotal & 0.742 & 0,349 & Valid \\
P8 dengan Ptotal & 0.703 & 0,349 & Valid \\
P9 dengan Ptotal & 0.743 & 0,349 & Valid \\
P10denganPtotal & 0.327 & 0,349 & Valid \\
\hline
\end{tabular}

\section{b. Uji Reliabilitas}

Uji Reliabilitas digunakan untuk mengetahui konsistensi alat ukur, apakah alat pengukur yang digunakan dapat diandalkan dan tetap konsisten 
jika pengukuran tersebut diulang [4]. Penelitian ini menggunakan metode cronbach's Alpha.

$$
r_{11}=\left(\frac{k}{k-1}\right)\left(1-\frac{\sum \sigma_{b}^{2}}{\sigma_{1}^{2}}\right)
$$

Keterangan :

$$
\begin{array}{ll}
\mathrm{r}_{11} & =\text { Reliabilitas Instrumen } \\
\mathrm{k} & =\text { Banyaknya butir pertanyaan } \\
\Sigma_{\mathrm{b}}{ }^{2} & =\text { Jumlah varians butir } \\
\sigma_{\mathrm{t}}{ }_{\mathrm{t}} & =\text { Varians total }
\end{array}
$$

Kriteria nilai alpha :

$0,8-1,0:$ sangat tinggi

$0,6-0,8:$ tinggi

$0,4-0,6$ : cukup

$0,2-0,4:$ rendah

$0,0-0,1$ : sangat rendah

Hasil uji Reliabilitas pada siswa SDIT ALHIKAM dalam tabel 2.

Hasil kuisioner untuk siswa memiliki reliabilitas yang tinggi.

Tabel 2. Hasil uji reliabilitas

\begin{tabular}{|c|c|}
\hline Nilai alpha & Kesimpulan \\
\hline 0,7 & Tinggi \\
\hline
\end{tabular}

\section{c. Hasil Presentase Interprestasi}

Hasil kuisioner dihitung rata-rata persentase interpretasi $(\mathrm{P})$ sesuai dengan pertanyaan yang telah disusun sebelumnya. Rumus Persentase Interpretasi / Skor Rata-rata $(\mathrm{P})$ :

$$
\text { Persentase Skor Rata }- \text { rata }=\frac{\sum \text { Skor yang diperoleh }}{\text { Skor maks }} \times 100 \%
$$

Dengan demikian diperoleh hasil Prosentase Interprestasi $(\mathrm{P})$ adalah:

$$
\begin{aligned}
& \mathrm{P} 1: \mathrm{P}=(143 / 150) \times 100 \%=95.3 \% \\
& \mathrm{P} 2: \mathrm{P}=(143 / 150) \times 100 \%=95.3 \% \\
& \mathrm{P} 3: \mathrm{P}=(146 / 150) \times 100 \%=97,3 \% \\
& \mathrm{P} 4: \mathrm{P}=(146 / 150) \times 100 \%=97,3 \% \\
& \text { P5 }: \mathrm{P}=(123 / 150) \times 100 \%=82 \% \\
& \text { P6 }: \mathrm{P}=(139 / 150) \times 100 \%=92,7 \% \\
& \text { P7 }: \mathrm{P}=(140 / 150) \times 100 \%=93,3 \% \\
& \text { P2 }: \mathrm{P}=(146 / 150) \times 100 \%=97,3 \%
\end{aligned}
$$

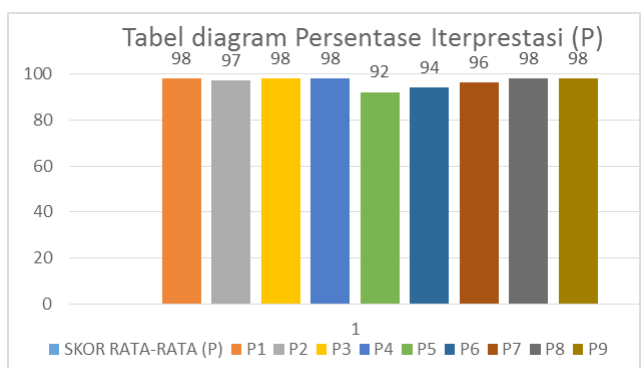

Gambar 11. Prosentase Iterprestasi (P)
Berdasarkan table diagram diatas dapat ditarik kesimpulan bahwa game ini menarik dan bagus dari segi tampilan dan grafik yang digunakan. Sehingga diharapkan mampu memenuhi tujuan pembuatan.

\section{Penutup}

Berdasarkan penelitian yang telah dilakukan, kesimpulan yang dapat diambil diantaranya :

1) Aplikasi Game Anti Narkoba berbasis multi-platform menggunakna Construct 2 dapat digunakan sebagai media bermain sambil belajar oleh masyarakat terutama anak-anak untuk mengenalkan dampak buruk narkoba dan menghindarkan orang untuk menyalahgunakan atau memakai narkoba.

2) Pengoperasian aplikasi bisa menggunakan PC, leptop dan Gadget yang mengunakan aplikasi Android.

3) Berdasarkan uji blackbox yang telah dilakukan dapat disimpulkan bahwa game ini dapat berjalan baik pada perangkat desktop baik dalam ekstensi .exe ataupun .html. Namun untuk perangkat mobile game ini hanya dapat berjalan pada spesifikasi tertentu.

4) Dari table dan grafik di atas dapat diketahui bahwa game ini dapat menarik minat $96,6 \%$ responden.

\section{Daftar Pustaka}

[1] Afiatin,T. (2008). Pencegahan Penyalahguanaan Narkoba Dengan Program AJI. Yogyakarta. Gajah Mada University Press.

[2] Dewi, G. (2012). Pengembangan Game Edukasi Pengenalan Nama Hewan Dalam Bahasa Inggris Sebagai Media Pembelajaran Siswa SD Berbasis Macromedia Flash. Skripsi.

[3] Edward, S, L. (2009). Learning Process and violent Video Games. Hand Book of reseach on Effective electronic Game in Education. Florida: University of Florida

[4] Nidra, S. \& Dondeti, J. (2012). Black Box And White Box Testing Techniques -A Literature Review. International Journal of Embedded Systems and Applications (IJESA), 2 (2).

[5] Priyatno,duwi.(2015). Paham Analisa Statistik Data dengan SPSS. MediaKom, Yogyakarta

[6] Sudarmilah, Endah., R. Ferdiana., L. E. Nugroho., A. Susanto. (2013). Tech review: Game platform for upgrading counting ability on Preschool Children. Prosiding on The 5th International Conference on Information Technology and Electrical Engineering. (ICITEE 2013).

[7] Williams, K. D. (2014). The effects of dissociation, game controllers, and $3 \mathrm{D}$ versus $2 \mathrm{D}$ on presence and enjoyment. Computers in Human Behavior, 38, 142150. http://doi.org/10.1016/j.chb.2014.05.040 